Journal of Applied Pharmaceutical Science Vol. 7 (03), pp. 024-030, March, 2017

Available online at http://www.japsonline.com

DOI: 10.7324/JAPS.2017.70305

ISSN 2231-3354 (cc) BY-NC-sa

\title{
Cytotoxic and antioxidant capacity of extracts from Vaccinium meridionale Swartz (Ericaceae) in transformed leukemic cell lines
}

\author{
Margarita González ${ }^{1,2}$, Ismael Samudio ${ }^{3}$, Luis Gonzalo Sequeda-Castañeda ${ }^{1,2^{*}}$, Crispín Celis ${ }^{1}$, José Iglesias ${ }^{4}$, \\ Ludis Morales $^{4 * *}$ \\ ${ }^{1}$ Chemistry Department, School of Sciences, Pontificia Universidad Javeriana, Bogotá, Colombia. ${ }^{2}$ Pharmacy Department, School of Sciences, Universidad \\ Nacional de Colombia, Bogotá, Colombia. ${ }^{3}$ Center of Drug Research and Development, Vancouver, Canada. ${ }^{4}$ Biochemistry and Nutrition Department, \\ School of Sciences, Pontificia Universidad Javeriana, Bogotá, Colombia.
}

\section{ARTICLE INFO \\ Article history: \\ Received on: 09/01/2017 \\ Accepted on: 18/02/2017 \\ Available online: 30/03/2017}

\section{Key words:}

Agraz, Vaccinium

meridionale Swartz,

Antioxidant capacity,

Cytotoxicity, Leukemia,

Colombia.

\begin{abstract}
Leukemia is one of the most common malignancies in children and represents a challenge to increase life expectancy. Many studies have been conducted with the aim to find natural compounds to fight cancer; however, chemotherapy is still the most widely used treatment despite side effects as harmful to patients. In this paper the antioxidant and cytotoxic capacity of Agraz extracts (Vaccinium meridionale) in OCI AML3 and MOLT4 cells using parallel Doxorubicin was evaluated. Extractions were made using 95\% methanol, methanoldistilled water (1:1), distilled water and juice. Antioxidant capacity was performed by radical cation 2,2'azinobis-3-ethylbenzothiazoline-6-sulfonic acid and 2,2-diphenyl-1-picryl-hydrazyl-hydrate methods, and phenols content was determined by Folin-Ciocalteu. The cytotoxic effect was evaluated on the viability of OCI AML3 and MOLT4 cells using 96-well plates for cell seeding by hemocytometer to $96 \mathrm{~h}$. The antioxidant capacity expressed as $50 \%$ inhibitory concentration was $1.7 \pm 0.1$ and $4.5 \pm 0.4 \mathrm{mg} / \mathrm{L}$ for methanol extracts by radical 2,2-diphenyl-1-picryl-hydrazyl-hydrate and radical cation 2,2'-azinobis-3-ethylbenzothiazoline-6sulfonic acid, respectively. The phenol content was found on $104.7 \pm 4.0$ and $1669.7 \pm 82.6 \mathrm{mg} \mathrm{AG} / 100 \mathrm{~g}$ for the methanol extract and lyophilized juice, respectively. A decrease in viability of OCI AML3 (24.4\%) and MOLT4 (23.0\%) cells was found when using Agraz methanolic extract, with Doxorubicin was $98.8 \%$ and $85.0 \%$ respectively.
\end{abstract}

\section{INTRODUCTION}

Antioxidant compounds show a great ability to scavenge free radicals contributing to the prevention of cardiovascular and neurological diseases among many others chronic diseases including cancer (Sutachan et al., 2012). Chronic diseases such as cancer, diabetes, neurodegenerative and cardiovascular diseases are characterized by an enhanced state of oxidative stress, which may result from the overproduction of reactive species and/or a decrease in antioxidant defenses.

The search for new chemical entities with antioxidant profile is still thus an emerging field on ongoing interest. The high diversity of plant species in Colombia has proven to be a source of many organic molecules with pharmacological

Corresponding Author

*E-mails: lsequeda@javeriana.edu.co,

**Email: ludis.morales@javeriana.edu.co properties (Thomas et al., 2012). Studies in some fruits and vegetables have shown to have a high content of antioxidants which has been recommended for frequent consumption. The current trend is the use of natural antioxidants so they can be used in food industry since it is presumed they do not cause health problems (Garzón et al., 2010; Abreu et al., 2014). Group of molecules commonly found in studies phytochemicals are flavonoids, these are characterized by their ability to scavenge free radicals which cause oxidative stress (Gaviria-Montoya et al., 2009) attributing them the prevention of cardiovascular, circulatory, cancer and neurological diseases among others (Alvarez-Castro et al., 2003; SequedaCastañeda et al., 2016). In the last two decades, studies on the antioxidant and cytotoxic capacity of plants and fruits have considerably increased due not only to the need to improve human health but also due to the development of new techniques for chemical analysis. 
<smiles>OC[C@H]1O[C@@H](Oc2cc3c(O)cc(O)cc3[o+]c2-c2ccc(O)c(O)c2)[C@H](O)[C@@H]1O</smiles>

Cyanidin 3-arabinoside ACD/IUPAC Name: 2-(3,4-Dihydroxyphenyl)-5,7dihydroxy-3-chromeniumyl $\beta$-L-arabinofuranoside

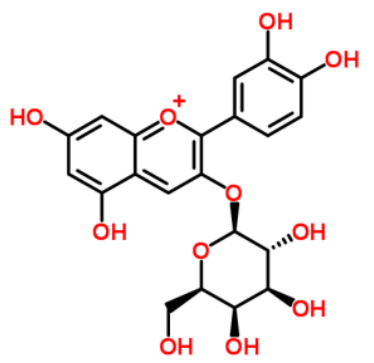

Cyanidin 3-galactoside (Ideain)

ACD/IUPAC Name: 2-(3,4-Dihydroxyphenyl)-5,7-dihydroxy-3-chromeniumyl $\beta$-D-galactopyranoside

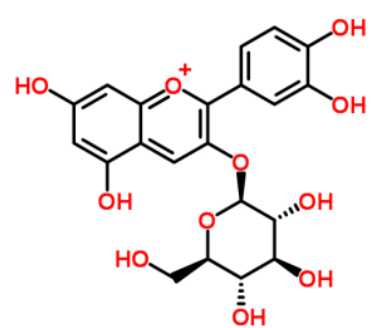

Cyanidin 3-glucoside ACD/IUPAC Name: 2-(3,4-Dihydroxyphenyl)5,7-dihydroxy-3-chromeniumyl $\beta$-Dglucopyranoside

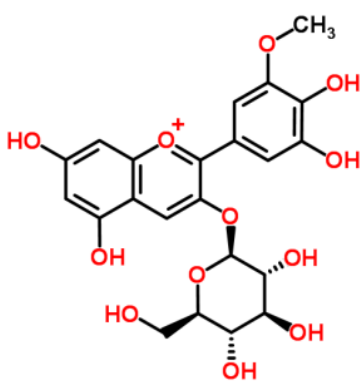

Petunidin 3-glucoside ACD/IUPAC Name: 2-(3,4-Dihydroxy-5methoxyphenyl)-5,7-dihydroxy-3-chromeniumyl $\beta$ D-glucopyranoside

Fig. 1: Compounds from Vaccinium meridionale Swartz (Ericaceae).

Table 1: Anthocyanin's present in Vaccinium meridionale Swartz (Eriaceae).

\begin{tabular}{cccc}
\hline Metabolite & Quantity & Method & Reference \\
\hline Cyanidin 3-galactoside, cyanidin 3-glucoside, & 201 mg per 100 g fresh weight & UV-Vis & (Gaviria-Montoya et al., 2009) \\
cyanidin 3-arabinoside, delphinidin 3-O- & 329 mg per 100 g fresh weight & HPLC-DAD. HPLC-ESI/MS-MS & (Garzón et al., 2010) \\
glucoside, petunidin 3-glucoside. & 151 mg per 100 g fresh weight & UV-Vis & (Maldonado-Celis et al., 2014) \\
& 539 mg per 100 g dry weight & HPLC-UV & (Lopera et al., 2013) \\
\hline
\end{tabular}

Regarding to different species of blueberries, several researches have determined the antioxidant capacity in different species (Canter et al., 2004; Prior et al., 1998) specifically in Vaccinium floribundum Kunth. (Vasco et al., 2009) in wild blackberries (Deighton et al., 2000), unripe fruits (Garzón et al., 2010) and other different kinds of berries (Kähkönen et al., 2001). One of the main compounds found with cytotoxic effect in them are anthocyanin's (Figure 1, Table 1) (Garzón et al., 2010; Gaviria-Montoya et al., 2009; Kamei et al., 1995; Lopera et al., 2013; Maldonado-Celis et al., 2014; H. Wang et al., 1999). Agraz has in its phytochemical composition cyanidin 3-glucoside at levels up to $329 \pm 28 \mathrm{mg} / 100 \mathrm{~g}$ (Garzón et al., 2010) compound to which it owes its high antioxidant potential of $45.5 \pm 2.3 \mathrm{~mol}$ $\mathrm{TE} / \mathrm{g}$; in addition to this antioxidant effect. The Vaccinium uliginosum agraz has showed high cytotoxicity in colon cancer strains ( $\mathrm{Zu}$ et al., 2010). Similarly, studies realized with cranberries have showed antioxidant-cytotoxic synergistic effect on ovarian cancer cells (Singh et al., 2009); using berries of French forests similar results have being achieved
(Bendaoud et al., 2010), demonstrating the association between the antioxidant potential and cytotoxicity (Wang et al., 2007) due to reactive oxygen species are involved in common pathways such as AP-1 and NF-kB, showing proapoptotic, antiinflammatory and anti-proliferative effects (Circu et al., 2010; Yang et al., 2001). Some anthocyanins and their glicones such as cianidine, pelargonin, delfidin exhibit antiproliferative and proapoptotic activities on gastric HT-29 adenosarcoma and colon Caco-2 cancer (Yi et al., 2005). Even though many studies have been conducted to find natural methods to fight cancer, chemotherapy keeps being the most common treatment for cancer despite the side harmful effects. It is known that using Doxorubicin provides a diminution of cell response between 40 and $50 \%$, but in turn causes nausea, mucositis and neutropenia risk of congestive cardiomyopathy (Winchester, 2001). In this research, we use Doxorubicin to compare and the aim was to evaluate the antioxidant capacity and potential cytotoxic effects of Agraz extracts on OCI AML3 and MOLT-4 cells and its possible application as an alternative treatment to prevent and / or fight cancer. 


\section{MATERIALS AND METHODS}

\section{Selection of plant material}

Ripe fruits of the Colombian blueberry (Vaccinium meridionale Swartz) commonly Agraz were selected without mechanical or microbiological changes, with good color characteristics, fleshy and edible appearance (Obtain commercially in Department of Boyacá into Santa Bárbara Zone in Tinjacá region). The National Herbarium of Colombia has classified this species under the voucher COL208724.

\section{Preparation of the Agraz Extract}

100 grams of ripe fruits were steeped in $200 \mathrm{~mL}$ of $\mathrm{MeOH}$ (95\%, acidulated with clorhidric acid $0.5 \mathrm{~N}$ to hydrolyze flavonoids glycosides), $200 \mathrm{~mL} \mathrm{MeOH} \mathrm{:} \mathrm{H}_{2} \mathrm{O}$ (1:1) and $200 \mathrm{~mL}$ of distilled $\mathrm{H}_{2} \mathrm{O}$ for 48 hours. The extracts were filtered using a cotton cloth, whatman filter paper \# 1 and concentrated by rotary evaporation $\left(90 \mathrm{rpm}\right.$ and $45^{\circ} \mathrm{C}$ ) to syrup, which is subsequently lyophilized and stored at $-80{ }^{\circ} \mathrm{C}$. The juice obtained by crushing the fruit was filtered, one part was preserved and another lyophilized (Raaman, 2006; Thangaraj, 2016).

\section{Preliminary phytochemical analysis}

The methanol extract $(568 \mathrm{mg})$, methanol-water extract $(485 \mathrm{mg})$, aqueous extract $(402 \mathrm{mg})$ and juice $(333 \mathrm{mg})$ were dissolved in $5 \mathrm{ml}$ of ethanol (EtOH) to perform the LiebermanBurchard test for steroids and sterols, Salkowski to terpenes, Baljet to terpenes and sterols, ferric hydroxamate for sesquiterpenlactones, Shinoda and ferric chloride for flavonoids, anthrone to flavonoid glycosides and Dragendroff for alkaloids (Raaman, 2006; Thangaraj, 2016).

\section{Total phenols}

The determination of total phenols was performed using the colorimetric method of Folin-Ciocalteu proposed by Singleton and modified by Ortiz-Ardila (Singleton et al., 1999; Ortíz-Ardila et al. 2017). Two milligrams of each separately lyophilized extract were placed in $50 \mathrm{~mL}$ volumetric flasks, adding deionized water until dissolved. Then a $0.5 \mathrm{ml}$ aliquot of each of these solutions were added $0.75 \mathrm{ml}$ of Folin-Ciocalteu $1.0 \mathrm{~N}$, allowed to stand at room temperature for 5 minutes and then added $0.75 \mathrm{ml}$ of sodium carbonate $20 \%$. The final solution was stored at room temperature in dark for 90 minutes. After this time the absorbance was measured at $760 \mathrm{~nm}$ using a spectrophotometer Thermo Genesys 10s. Results were expressed as milligrams of Gallic Acid per 100 grams of extract (mg GA/100 g).

\section{Antioxidant activity}

The antioxidant capacity was evaluated by the methods DPPH (1,1-Diphenyl-2-picryl-hydrazyl) and ABTS (2,2'-Azinobis(3-ethylbenzothiazoline-6-sulphonic acid). $10 \mathrm{mg}$ of the radical DPPH were diluted in $10 \mathrm{~mL}$ of $\mathrm{MeOH}$ and analytical absorbance at $516 \mathrm{~nm}$ was adjusted to $0.75 \pm 0.05$ by dilution (Brand-Williams et al., 1995; Ortíz-Ardila et al., 2017). The lyophilized extract was diluted in deionized water to obtain a $5000 \mathrm{ppm}$ stock and prepared 5 different concentrations: 50, 500, 1500, 3000 and 4500 ppm. From each solution, $25 \mu \mathrm{L}$ were added to $975 \mu \mathrm{L}$ of radical DPPH previously prepared to reach a final volume of $1 \mathrm{~mL}$. The steady state was reached in 30 minutes, and the inhibition $\%$ was calculated as follows: \% I $=[(\mathrm{Ao}-\mathrm{Ae}) / \mathrm{Ao}] \times 100$, where Ao corresponds to the absorbance of the solution of the radical without extract and Ae is referred as the absorbance to the radical plus the extract.

With the percentages of inhibition, scatterplots were obtained (\% inhibition vs. concentration of the extract), in order to get the equation of the line $(\mathrm{Y}=\mathrm{mX}+\mathrm{b})$ from which the $50 \%$ inhibitory concentration $\left(\mathrm{IC}_{50}\right)$ was calculated: $(50-\mathrm{b}) / \mathrm{m}$, being b the cut point in the $\mathrm{Y}$ axis, and $\mathrm{m}$ is the slope. The results were compared using Trolox and vitamin C (Kuskoski et al., 2005). For the Agraz juice (not lyophilized extract) the antioxidant capacity was determined by adding different volumes $(10 \mu \mathrm{L}, 20 \mu \mathrm{L}, 30 \mu \mathrm{L}$, etc). To calculate the values of the density and total solids in the juice AOAC 920.151 method and AOAC 950.28 method respectively were used (AOAC, 2011a, 2011b; RodríguezRodríguez et al., 2012). From the value of the total solids and density of the juice the $\mathrm{IC}_{50}$ was found.

ABTS radical was prepared by dissolving $10 \mathrm{mg}$ of the compound in $10 \mathrm{~mL}$ of water and then $2.4 \mathrm{mg}$ of potassium persulfate were added. The prepared solution was left at room temperature 16 hours in dark until find an absorbance of $0.72 \pm$ 0.02 at a wavelength of $735 \mathrm{~nm}$ (Re et al., 1999; Ortíz-Ardila et al., 2017). Five different concentrations of each extract between $100 \mathrm{ppm}$ and $4000 \mathrm{ppm}$ from a $5000 \mathrm{ppm}$ stock; the absorbance vs. time graphic was performed to determine the steady state. The inhibition $\%$ was calculated and the $\mathrm{IC}_{50}$ was obtained from the equation of line. For the Agraz juices the same procedure was carried out.

\section{Measurement of the effect on OCI-AML3 and MOLT4 cells viability}

Cell lines OCI-AML3 and MOLT4 were maintained in RPMI-1640 medium containing 5\% FCS, $1 \%$ glutamine and 100 units $/ \mathrm{mL}$ penicillin incubated at $37{ }^{\circ} \mathrm{C}$ and $5 \% \quad \mathrm{CO}_{2}$. Characterization of the viability effect of the Agraz extracts and Doxorubicin was measured at the third day of culture. From the homogenized contents a $1000 \mu \mathrm{L}$ aliquot of the cell suspension were plated and the cells were counted by hemocytometer (Phelan et al., 1997). Tests were performed in $96-w e l l$ plates by seeding $100 \mu \mathrm{L}$ of RPMI plus cells, adjusting its concentration to $10^{6}$ cells/well (Handbook, 2011; Licor, 2010).

The lyophilized agraz methanol extract was applied to the wells at concentrations of 10,50 and $100 \mu \mathrm{g} / \mathrm{mL}$ (using water as dissolvent) for both cell lines, as a control a concentration of 0 $\mu \mathrm{g} / \mathrm{mL}$ was used. The results were correlated with viability test using Doxorubicin at concentrations of 10,25 and $50 \mathrm{ng} / \mathrm{mL}$, as a control concentration $0 \mathrm{ng} / \mathrm{mL}$ was used. After dosing, each plate was stored in an incubator at $37{ }^{\circ} \mathrm{C}$ with $5 \% \mathrm{CO}_{2}$ and the live cells 
were counted by hemocytometer with trypan blue (Phelan et al., 1997; Thorkild et al., 1985) at 48, 72 and 96h. The viability percentage reduction caused by the extract and Doxorrubicin was calculated, results were expressed in $\mu \mathrm{g} / \mathrm{mL}$ of extract and in ng/mL of Doxorubicin (Licor, 2010; Phelan et al., 1997).

\section{Statistical analysis}

The software IBM SPSS Statistics 19 was used. All experiments were done in triplicate $(n=3)$ and results were expressed as means \pm standard deviations. Analysis of variance was analysed using the Tukey HSD test based on significant difference of $\mathrm{p}<0.05$.

\section{RESULTS AND DISCUSSION}

\section{Agraz extracts}

The extracts of different polarities were obtained from $100 \mathrm{~g}$ of fresh fruit. The extract yield for each polarity was $2.3 \pm$ $0.5 \%, 1.8 \pm 0.4 \%$ and $1.2 \pm 0.3 \%$ for methanol extract, methanol-water extrac (1:1) and water extract, respectevely.

\section{Preliminary phytochemical analysis}

The results of qualitative chemical tests (Table 2) show high similarity between the compounds present in the Agraz juice and extracts using solvents such as methanol, methanol-water (1:1) and water. The compounds detected correspond to phenols and tannins, flavonoids, terpenes, terpene lactones, coumarins and steroids.

Table 2: Preliminary phytochemical analysis.

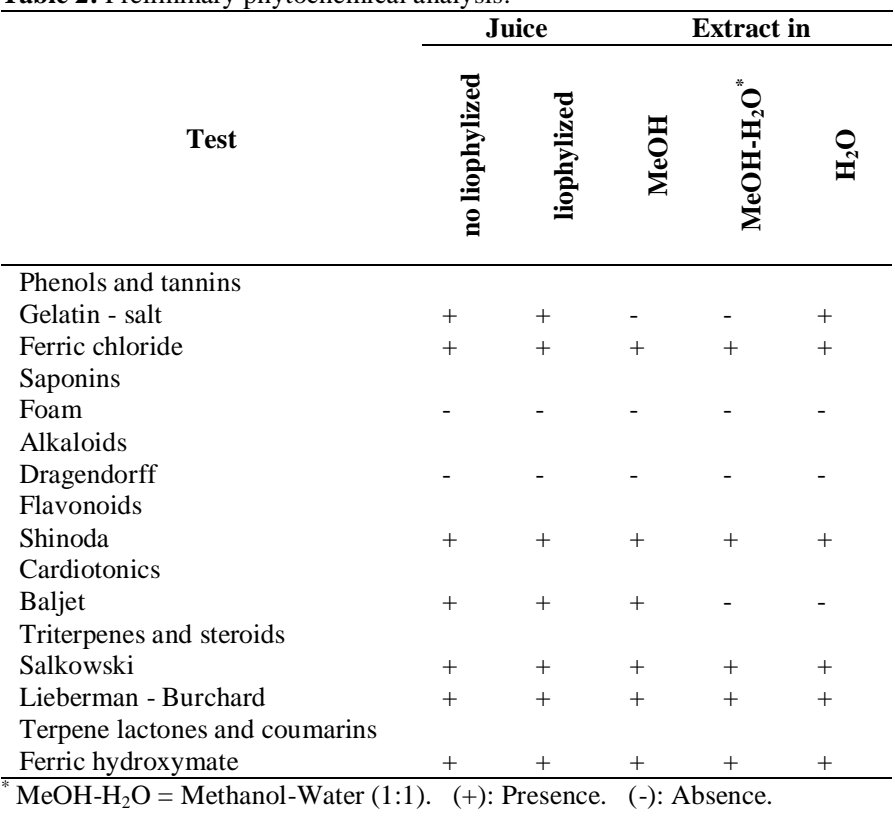

\section{Antioxidant capacity and total phenols content}

The results show the largest amount of total phenols for the not lyophilized and lyophilized Agraz juice $233.4 \pm 7.6$ and
$1669.7 \pm 82.6 \mathrm{mg} \mathrm{GA} / 100 \mathrm{~g}$ respectively, compared to the extracts obtained with solvents such as methanol (104.7 $\pm 4.0 \mathrm{mg}$ GA/100g), methanol-water $(32.9 \pm 3.5 \mathrm{mg} \mathrm{GA} / 100 \mathrm{~g})$ and water (79.4 $\pm 6.4 \mathrm{mg} \mathrm{GA} / 100 \mathrm{~g})$ (Table 3).

Table 3: Total phenolic content in Agraz extracts and juice.

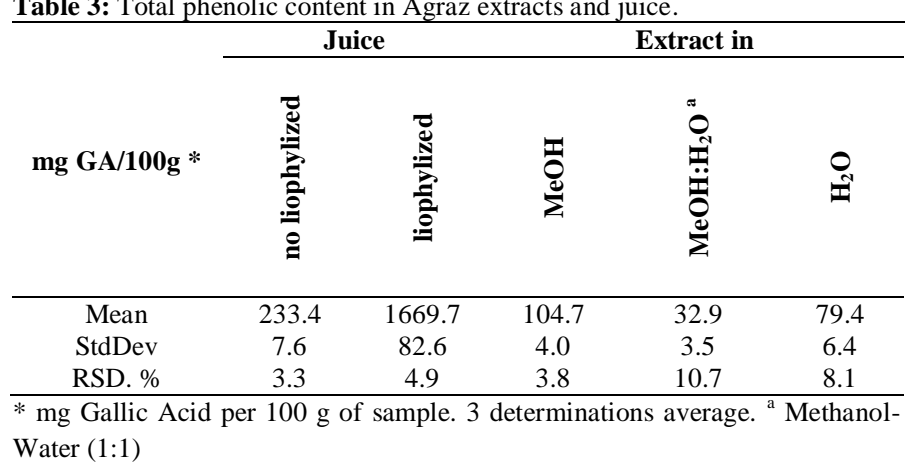

Garzón et al., in 2010 reported $758.6 \pm 62.3 \mathrm{mg} \mathrm{GA} / 100 \mathrm{~g}$ in methanolic extract after subjecting the fruits to liquid nitrogen; not lyophilized and lyophilized Agraz juice showed the highest concentration of total phenolic compounds compared to other berries such as Vaccinium floribundum of Ecuador whose amount is $882 \mathrm{mg} \mathrm{GA} / 100 \mathrm{~g}$ (Vasco et al., 2009), Vaccinium myrtillus of North America in $525 \mathrm{mg}$ GA/100g and between 190-473 mg GA/100g for Vaccinium corymbosum, Vaccinium asheiy and Vaccinium angustifolium (Garzón et al., 2010). In Vaccinium meridionale $86 \pm 4 \mathrm{mg} \mathrm{GA} / 100 \mathrm{~g}$ in the methanol extract was reported (Sequeda-Castañeda et al., 2016), whereas in this study for the same type extract was $104.7 \mathrm{mg}$ GA/100g. Among the extracts, the methanolic has the best $\mathrm{IC}_{50}$ and has the highest total phenolic content. The amount of total phenols in the different extracts was lower than that found in the juice (without lyophylized and lyophilized). Possibly due to differences in solubility to total phenols present in the solvents used. Additionally, the lyophilization process substantially increase the phenol content in the lyophilized juice because the process removes the water present in the juice and increase the content of solutes (solids). All samples have high antioxidant capacity. The extract with the highest antioxidant capacity expressed as $\mathrm{IC}_{50}$ correspond to the methanol extract with values of $1.7 \pm 0.1 \mathrm{mg} / \mathrm{L}$ (DPPH method) and $4.1 \pm 0.3 \mathrm{mg} / \mathrm{L}$ (ABTS method). While controls showed values of $3.1 \pm 0.2 \mathrm{mg} / \mathrm{L}$ (ABTS method) and $20.8 \pm 1.2 \mathrm{mg} / \mathrm{L}$ (DPPH method) for Trolox and $2.4 \pm 0.2$ and 3.5 $\pm 0.3 \mathrm{mg} / \mathrm{L}$ for ABTS and DPPH methods, respectively for ascorbic acid (Table 4). In another study the IC50's were $3.8 \pm 0.3$ and $22.9 \pm 5.4 \mathrm{mg} / \mathrm{L}$ in ABTS and DPPH methods, respectively, for methanol extract (Sequeda-Castañeda et al., 2016); these values are lower than those reported in this study. The high antioxidant capacity is probably to its higher content of anthocyanins, phenols and a different polyphenols (Lopera et al., 2013). 
Table 4: Antioxidant capacity for Agraz juice and extracts*

\begin{tabular}{|c|c|c|c|c|c|c|c|c|}
\hline \multirow{3}{*}{$\mathrm{IC}_{50}{ }^{\mathrm{a}}(\mathrm{mg} / \mathrm{L})$} & \multicolumn{6}{|c|}{ Agraz extracts in: } & \multirow{2}{*}{\multicolumn{2}{|c|}{ Trolox $^{c}$}} \\
\hline & \multicolumn{2}{|c|}{ МeOH } & \multicolumn{2}{|c|}{$\mathrm{MeOH}: \mathrm{H}_{2} \mathrm{O}^{\mathrm{b}}$} & \multicolumn{2}{|c|}{$\mathrm{H}_{2} \mathrm{O}$} & & \\
\hline & ABTS & DPPH & ABTS & DPPH & ABTS & DPPH & ABTS & DPPH \\
\hline Mean & 4.1 & 1.7 & 74.5 & 16.9 & 17.6 & 3.9 & 3.1 & 20.8 \\
\hline StdDev & 0.3 & 0.1 & 4.6 & 1.1 & 1.3 & 0.3 & 0.2 & 1.2 \\
\hline RSD. $\%$ & 7.3 & 5.9 & 6.2 & 6.5 & 7.4 & 7.7 & 6.5 & 5.8 \\
\hline \multirow{3}{*}{$\mathrm{IC}_{50}{ }^{\mathrm{a}}(\mathrm{mg} / \mathrm{L})$} & \multicolumn{4}{|c|}{ Juice } & \multirow{2}{*}{\multicolumn{2}{|c|}{ Vitamine $C^{b}$}} & & \\
\hline & \multicolumn{2}{|c|}{ no liophylized } & \multicolumn{2}{|c|}{ liophylized } & & & & \\
\hline & ABTS & DPPH & ABTS & DPPH & ABTS & DPPH & & \\
\hline Mean & 4.5 & 5.5 & 23.7 & 35.6 & 2.4 & 3.5 & & \\
\hline StdDev & 0.4 & 0.5 & 1.3 & 2.7 & 0.2 & 0.3 & & \\
\hline RSD. $\%$ & 8.9 & 9.1 & 5.5 & 7.6 & 8.3 & 8.6 & & \\
\hline
\end{tabular}
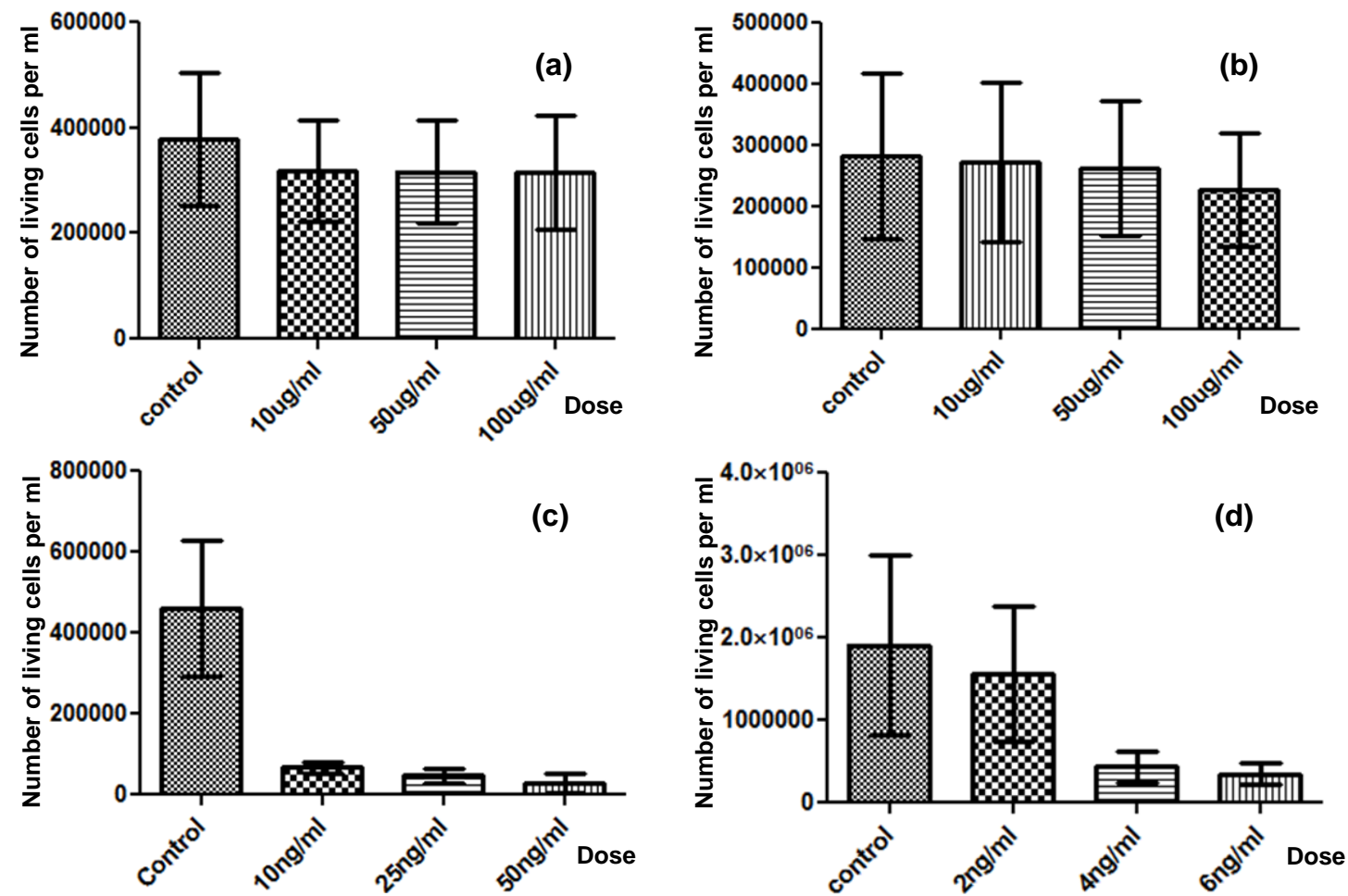

Fig. 2: Cell viability of (a) OCI AML3 cells with methanolic extract of Agraz. (b) MOLT4 cells with methanolic extract of Agraz. (c) OCI AML3 cells with Doxorubicin. (d) MOLT4 cells with Doxorubicin. Three different experiment with three replicates (wells) each one $(\mathrm{n}=3$ ). Significance values ( $\mathrm{p}>0.05)$ was calculated with Tukey's test.

Effect of the Agraz extract in $\mathrm{MeOH}$ and Doxorubicin on cell viability of OCI-AML3 and MOLT4 cells

The methanol extract was selected to evaluate the effect on cell viability because it presented the best antioxidant capacity $\left(\mathrm{IC}_{50}\right.$ of 4.1 and $1.7 \mathrm{mg}$ per L for ABTS and DPPH methods, respectively). The viability in OCI-AML3 cells decreased by 11.8 , 20.8 and $24.4 \%$ for doses of 10,50 and $100 \mathrm{~g} / \mathrm{mL}$ respectively. While the MOLT4 cells showed 2.4, 12.8 and 23.0\% with doses of 10,50 and $100 \mathrm{~g} / \mathrm{mL}$. The effect of Doxorubicin in inhibiting the viability of OCI-AML3 cells was $84.1,91.3$ and $98.8 \%$ for doses of 10,25 and $50 \mathrm{ng} / \mathrm{ml}$ respectively. In MOLT4 cells the decrease was 29.0, 81.0 and $85.0 \%$ when using doses of 2.0, 4.0 and 6.0 $\mathrm{ng} / \mathrm{mL}$, respectively (Figure 2). The decrease OCI-AML3 cells viability with the methanolic Agraz extract was statistically significant (sig $0.000 \mathrm{p} \leq 0.05$ ) among all the means of the tested concentrations. While the decrease for MOLT4 cells was not significant (sig $0.969 \mathrm{p} \leq 0.05$ ). Observed decrease in cell viability percentage was much lower compare to standard drug doxorubicin in all cases. The mechanism by which the extract inhibits cell proliferation may be due to the induction of apoptosis (Shih et al., 2005) by NF-kB and AP1 pathways (Wang et al., 2007) or by inhibition of certain enzymes such as cyclooxygenase (Seeram $e t$ al., 2003), however further investigation must be addressed.

\section{Antioxidants used in leukemia and their relation with chemotherapy side effects}

Some plants and fruits rich in antioxidant content as ginger root, grapes, carrot, black and blueberries etc. have been 
used for leukemia treatment (Saedi et al., 2014). Different authors reported that antioxidant use during chemotherapy decreases mucositis (Wadleigh et al., 1992) and that a lower consumption of vitamins and antioxidants was related to an increased risk of a delay in therapy or of experiencing hematologic or nonhematologic toxicity in kids with leukemia (Kennedy et al., 2004).

However, remains to clarify the basis of the mechanisms by which antioxidants would be mediating the reduction of some of the side effects of chemotherapy in patients with leukemia. Thus, our study provides a basis for continuing research on the potential for dietary and pharmaceutical antioxidants to enhance the effects of chemotherapy and decrease toxicity without interfering with oncological proceeding.

\section{CONCLUSION}

The Agraz juice and methanolic extract show a high antioxidant value per the results of the ABTS and DPPH assays. Even though the cytotoxic tests with the Agraz methanolic extract did not yield high percentages of decreasing viability of OCIAML3 and MOLT4 cells, the Agraz juice -both lyophilized and non-lyophilized- might be a potentially cytotoxic source because of its high antioxidant capacity and total phenolic content. Regarding to Doxorubicin, this showed a greater effect in decreasing the proliferation of OCI-AML3 (98.8\%) and MOLT4 (85\%) cells than that obtained with the Agraz methanolic extract for OCI AML3 cells (24.4\%) and MOLT4 $(23.0 \%)$.

\section{ACKNOWLEDGMENTS}

Administrative Department of Science, Technology and Innovation -COLCIENCIAS-. This work was funded by the Academic Vice-Rectory and Vice-Rectory for Research of the Pontificia Universidad Javeriana (Project 4033 - Evaluation of antioxidant and antitumor capacity in four fruits of commercial interest in Colombia). Thanks to the Experimental and Computational Biochemistry Group and to the Phytochemistry Research Group at the Pontificia Universidad Javeriana for their support and collaboration in the realization of this study.

Conflict of Interests: There are no conflicts of interest.

\section{REFERENCES}

Abreu OA, Barreto G, Prieto S. Vaccinium (Ericaceae): Ethnobotany and pharmacological potential. Emir J Food Agric, 2014; 26(7):577-591

Alvarez-Castro E, Orallo-Cambeiro. Actividad biológica de los flavonoides (I). Acción frente al cáncer. Offarm, 2003; 22(10):130-140.

AOAC. 2011a. Official Method 920.151 Solids (Total) in Fruits and Fuit Products AOAC Official Methods of Analysis (OM2003A) 18 th Edition: AOAC INTERNATIONAL

AOAC. 2011b. Official Method 950.28 Specific Gravity of Nonalcoholic Beverages. AOAC Official Methods of Analysis (OMA) 18th Edition: AOAC INTERNATIONAL.
Bendaoud H, Romdhane M, Souchard JP, Cazaux S, Bouajila J. Chemical composition and anticancer and antioxidant activities of Schinus molle L. and Schinus terebinthifolius Raddi berries essential oils. J Food Sci, 2010; 75(6):C466-C472.

Brand-Williams W, Cuvelier ME, Berset C. Use of a Free Radical Method to Evaluate Antioxidant Activity. Lebensm-Wiss uTechnol, 1995; 28(1):25-30.

Canter PH, Ernst E. Anthocyanosides of Vaccinium myrtillus (Bilberry) for Night Vision-A Systematic Review of Placebo-Controlled Trials. Survey Ophthalmol, 2004; 49(1):38-50.

Circu ML, Aw TY. Reactive oxygen species, cellular redox systems, and apoptosis. Free Radic Biol Med, 2010; 48(6):749-762.

Deighton N, Brennan R, Finn C, Davies HV. Antioxidant properties of domesticated and wild Rubus species. J Sci Food Agric, 2000; 80(9):1307-1313.

Garzón GA, Narváez CE, Riedl KM, Schwartz SJ. Chemical composition, anthocyanins, non-anthocyanin phenolics and antioxidant activity of wild bilberry (Vaccinium meridionale Swartz) from Colombia. Food Chem, 2010; 122(4):980-986.

Gaviria-Montoya C, Ochoa-Ospina C, Sánchez-Mesa N, Medina-Cano C, Lobo-Arias M, Galeano-García P, Mosquera-Martínez A, Tamayo-Tenoria A, Lopera-Pérez Y, Rojano, B. Antioxidant activity and inhibition of lipid peroxidation of mortiño fruits extracts (Vaccinium meridionale SW). Bol Latinoam Caribe Plant Med Aromat, 2009; 8(6):519-528.

Handbook E. 2011. Fundamental Techniques in Cell Culture Laboratory Handbook. The European Collection of Cell Cultures. [ONLINE] Available at: http://www.sigmaaldrich.com/life-science/cellculture/learning-center/ecacc-handbook.html. [Accessed 09 July 2014].

Kähkönen MP, Hopia AI, Heinonen M. Berry Phenolics and Their Antioxidant Activity. J. Agric. Food Chem, 2001; 49(8):4076-4082.

Kamei H, Kojima T, Hasegawa M, Koide T, Umeda T, Yukawa $\mathrm{T}$, Terabe K. Suppression of tumor cell growth by anthocyanins in vitro. Cancer Invest, 1995; 13(6):590-594.

Kennedy D,Tucker KL, Ladas ED, Rheingold SR, Blumberg J, Kelly KM. Low antioxidant vitamin intakes are associated with increases in adverse effects of chemotherapy in children with acute lymphoblastic leukemia1-3. Am J Clin Nutr, 2004; 79:1029-1036.

Kuskoski EM, Asuero AG, Troncoso AM, Mancini-Filho J, Fett R. Aplicação de diversos métodos químicos para determinar atividade antioxidante em polpa de frutas. Ciênc Tecnol Aliment Campinas, 2005; 25(4):726-732.

Licor. 2010. In-Cell Western Assay. FAQs For Suspension Cells For In-Cell Western ${ }^{\mathrm{TM}}$ Protocols. [ONLINE] Available at: http://biosupport.licor.com/docs/ICW_Susp_FAQ_11461.pdf. [Accessed 05 May 2014]

Lopera YE, Fantinelli J, Gonzalez-Arbelaez LF, Rojano B, Rios JL, Schinella G, Mosca S. 2013. Antioxidant Activity and Cardioprotective Effect of a Nonalcoholic Extract of Vaccinium meridionale Swartz during Ischemia-Reperfusion in Rats. Evid Based Complement Alternat Med, 2013; ID516727.

Maldonado-Celis ME, Arango-Varela SS, Rojano BA. Free radical scavenging capacity and cytotoxic and antiproliferative effects of Vaccinium meridionale Sw. agains colon cancer cell lines. Rev Cubana Plant Med, 2014; 19(2):172-184.

Ortiz-Ardila AE, Correa-Cuadros JP, Celiz-Zambrano CA, Rodriguez-Bocanegra MX, Robles-Carmargo J, Sequeda-Castañeda LG. Antioxidant and Antimicrobial capacity of Cecropia mutisiana Mildbr. (Cecropiaceae) leave extracts. Emir J Food Agric, 2017; 29(1):2535 .

Phelan MC, Lawler G. 1997. Cell Counting. In: John Wiley \& Sons (Ed.), Current Protocols in Cytometry.

Prior RL, Cao G, Martin A, Sofic E, McEwen J, O'Brien C, Lischner N, Ehlenfedt M, Kalt W, Krewer G, Mainlad, M. Antioxidant Capacity As Influenced by Total Phenolic and Anthocyanin Content, Maturity, and Variety of Vaccinium Species. J Agric Food Chem, 1998; 46(7):2686-2693.

Raaman, N. 2006. Phytochemical Techniques. New Delhi: New India Publishing Agency. 
Re R, Pellegrini N, Proteggente A, Pannala A, Yanga M, RiceEvans C. Antioxidant activity applying an improved ABTS radical cation decolorization assay. Free Radic Biol Med, 1999; 26(9-10):1231-1237.

Rodríguez-Rodríguez JC, Samudio-Echeverry IJP, SequedaCastañeda LG. Evaluation of the Antibacterial Activity of Four Ethanolic Extracts of Bryophytes and Ten Fruit Juices of Commercial Interest in Colombia against Four Pathogenic Bacteria. Acta Hort, 2012; 264(1):251257.

Saedi TA, Noor SM, Ismail P, Othman F. The Effects of Herbs and Fruits on Leukaemia. Evid Based Complement Alternat Med, 2014; 2014: 494136

Seeram NP, Zhang Y, Nair MG. Inhibition of Proliferation of Human Cancer Cells and Cyclooxygenase Enzymes by Anthocyanidins and Catechins. Nutr Cancer, 2003; 46(1):101-106.

Sequeda-Castañeda LG, Barrera-Bugallo AR, Celis C, Iglesias J, Morales L. Evaluation of antioxidant and cytotoxic activity of extracts from fruits in fibroblastoma HT1080 cell lines: four fruits with commercial potential in Colombia. Emir J Food Agric, 2016; 28(2):143151

Shih PH., Yeh CT, Yen GC. Effects of anthocyanidin on the inhibition of proliferation and induction of apoptosis in human gastric adenocarcinoma cells. Food Chem Toxicol, 2005; 43(10):1557-1567.

Singh AP, Singh RK, Kim KK, Satyan KS, Nussbaum R, Torres M., Brard L, Vorsa N. Cranberry Proanthocyanidins are Cytotoxic to Human Cancer Cells and Sensitize Platinum-Resistant Ovarian Cancer Cells to Paraplatin. Phytother Res, 2009; 23(8):1066-1074.

Singleton VL, Orthofer R, Lamuela-Raventós RM. Analysis of total phenols and other oxidation substrates and antioxidants by means of folin-ciocalteu reagent. Methods in enzymology, 1999; 299(C):152-178.

Sutachan JJ, Casas Z, Albarracin SL, Stab BR, Samudio I, Gonzalez J, Morales L, Barreto GE. Cellular and molecular mechanisms of antioxidants in Parkinson's disease. Nutr Neurosci, 2012; 15(3):120126

Thangaraj P. 2016. Pharmacological Assays of Plant-Based Natural Products, Switzerland, Springer International Publishing.

Thomas CM, Wood RC, Wyatt JE, Pendleton MH, Torrenegra RD, Rodriguez OE, Harirforoosh S, Ballester M, Lightner J, Krishnan K, Ramsauer VP. Anti-neoplastic activity of two flavone isomers derived from Gnaphalium elegans and Achyrocline bogotensis. PLoS One, 2012; 7(6):e39806
Thorkild C, Hansen B. 1985. Proceedings of the IUB Symposium No. 144: The Seventh International Lectin Meeting, Bruxelles, Belgium, August 18-23.

Vasco C, Riihinen K, Ruales J, Kamal-Eldin A. Chemical Composition and Phenolic Compound Profile of Mortiño (Vaccinium floribundum Kunth). J Agric Food Chem, 2009; 57(18):8274-8281.

Wadleigh R, Redman R, Graham M , Krasnow S , Anderson A , Cohen M.Vitamin E in the treatment of chemotherapy-induced mucositis . Am J Med, 1992; 92:481-484 .

Wang H, Nair MG, Strasburg GM, Chang YC, Booren AM, Gray JI, DeWitt DL. Antioxidant and antiinflammatory activities of anthocyanins and their aglycon, cyanidin, from tart cherries. J Nat Prod, 1999; 62(2):294-296.

Wang SY, Feng R, Bowman L, Lu Y, Ballington JR, Ding M. Antioxidant Activity of Vaccinium stamineum: Exhibition of Anticancer Capability in Human Lung and Leukemia Cells. Planta Med, 2007; 73(5):451-460.

Winchester, D. J. 2001. Cáncer de mama. Atlas de oncología clínica. Madrid: Elsevier España.

Yang CS, Landau JM, Huang MT, Newmark HL. Inhibition of carcinogenesis by dietary polyphenolic compounds. Annu Rev Nutr, 2001; 21:381-406.

Yi W, Fischer J, Akoh CC. Study of anticancer activities of muscadine grape phenolics in vitro. . J Agric Food Chem, 2005; 53(22):8804-8812.

Zu XY, Zhang ZY, Zhang XW, Yoshioka M, Yang YN, Li J. Anthocyanins extracted from Chinese blueberry (Vaccinium uliginosum L.) and its anticancer effects on DLD-1 and COLO205 cells. Chin Med J, 2010; 123(19):2714-2719.

\section{How to cite this article:}

González M, Samudio I, Sequeda-Castañeda LG, Celis C. Cytotoxic and antioxidant capacity of extracts from Vaccinium meridionale Swartz (Ericaceae) in transformed leukemic cell lines. J App Pharm Sci, 2017; 7 (03): 024-030. 